\title{
Effect of Biochar Application on Heavy Metal Mobility in Soils Impacted by Copper Smelting Processes
}

\author{
Agnieszka Medyńska-Juraszek*, Irmina Ćwieląg-Piasecka \\ Institute of Soil Sciences and Environmental Protection, Wroclaw University of Environmental and Life Sciences, \\ Wrocław, Poland
}

Received: 27 February 2019

Accepted: 24 April 2019

\begin{abstract}
Biochar seems to be a very promising material for remediation, reducing heavy metal mobility in contaminated sites. However, the effect of its application on soil depends on biochar origin, pyrolysis condition, soil type and properties like initial $\mathrm{pH}$ or cation exchange capacity, and also on metal form and interactions. This makes prediction about successful remediation with biochar more difficult and a lot of attention should be paid to choose the proper material appropriate to soil conditions. The aim of our study was to evaluate wheat straw biochar application on multi-contaminated soil, to decrease their mobility and minimize the risk of heavy metal occurrence in the area impacted by copper smelting processes. The results of this study indicate that wheat straw biochar application can potentially reduce $\mathrm{Cu}, \mathrm{Pb}, \mathrm{Zn}$ or $\mathrm{Cd}$ mobility only in sandy or acidified soils due to the liming effect. In alkaline soils the effect of biochar application on metal immobilization was imperceptible. The effect of wheat straw biochar on heavy metal immobilization in multi-contaminated soils is more complex and cannot be defined as all-purpose material in remediation procedures.
\end{abstract}

Keywords: soil pollution, heavy metal, biochar, remediation

\section{Introduction}

Heavy metals are naturally present in soils but may be enhanced due to anthropogenic activities such as metal ore mining and smelting processes. Poland is one of the biggest copper producers, contributing 3.6\% of the global copper market. More than 70 years of copper industry development in SW Poland has resulted in significant pollution of soils in the vicinity of mining

*e-mail: agnieszka.medynska-juraszek@upwr.edu.pl and smelting sites. Initially high acidification of soils due to high emissions of sulfur dioxide from smelting and secondary mobilization of heavy metals such as lead $(\mathrm{Pb})$, copper $(\mathrm{Cu})$, cadmium $(\mathrm{Cd})$, zinc $(\mathrm{Zn})$ or arsenic (As) has led to serious chemical degradation of soils and the exclusion of large areas from agricultural use. Even if the scale of these activities is local, it may cause widespread environmental pollution and should be considered as sources of environmental and health risks associated with the transfer of heavy metals to the food chain and human exposure. To reduce the risk, the bioavailability of heavy metals can be modified, leading to the decrease of their accumulation and toxicity in 
the food chain. Like activated carbon, biochar is a solid material obtained in an oxygen-limited environment through the thermochemical transformation (pyrolysis) of biomass [1], but the source materials are generally limited to a large variety of biological residues, e.g., wood, municipal green waste, crop residues, sewage sludge $[2,3]$ and not commonly activated or further treated before application to soils. Biochars, depending on feedstock type and conditions of pyrolysis, consist of different proportions of carbonized and amorphous organic matter [4, 5]. Typically, most biochars have a large surface area [6], a microporous structure [7], active organic functional groups $[5,8]$ contain dissolved organic carbon [9] and have high $\mathrm{pH}$ [10], which makes this material a strong and effective sorbent for both organic and inorganic soil pollutants [11]. Numerous studies have shown that biochar has the potential to remediate soils contaminated with heavy metals and seems to be an attractive alternative to standard materials used in in situ soil remediation [4, 12-15]. One of the main properties controlling metal fate and mobility in contaminated sites is soil $\mathrm{pH}$. The primary mechanisms of metal immobilization by biochar in soils include an increase of soil $\mathrm{pH}$ [16], ion exchange with acidic functional groups [17], physical sorption [18] and precipitation [13]. Mechanisms of $\mathrm{pH}-$ dependent heavy metal immobilization differs under soil conditions. Adsorption reactions dominate in acidic conditions, while precipitation or the formation of hydroxide complexes, phosphates or carbonates [6] occur at alkaline $\mathrm{pH}$. Secondary mechanisms of element sorption/desorption processes are influenced by particle size distribution and properties of soil sorption complex (cation exchange capacity, organic matter and clay minerals content). In sandy soils metals are present mainly in soil solution, while in loamy or heavy clay soils they are immobilized on soil constituents. In multi-contaminated soils metal competition for binding sites should also be considered [19]. Understanding the extractability and therefore availability of metals in biochar-amended soils is important when using biochar for remediation purposes. Recently, the effects of biochar on heavy metal mobility have been widely reported, both in the field and under laboratory conditions, mainly via column leaching test [16, 20-23]. Published results give very opposite feedback of biochar potential in heavy metal immobilization. Most studies have focused on flooded paddy soils, while mechanisms may vary in more arid soils due to different redox conditions, different organic matter content or lower solubility of elements. Also, knowledge about zinc immobilization by organic sorbents is very limited. As an essential nutrient for living organisms, it is not usually considered as a toxic element. However, an excess supply of this element, that can take place in soils impacted by multi-elemental emissions from smelting processes can become toxic to plants and soil microorganisms. Probably an all-purpose remediation method with biochar is too difficult to achieve, as different biochars, depending on feedstock type or pyrolysis temperature, will have very diverse sorption properties.

Therefore, this study was conducted to evaluate changes in $\mathrm{Cu}, \mathrm{Zn}, \mathrm{Pb}$ and $\mathrm{Cd}$ mobility in two contrasting soils impacted by copper smelting emissions after wheat straw biochar application. The results presented in the study will provide a useful reference for developing new strategies of soil remediation and protection - especially in areas under agricultural use.

\section{Experimental}

\section{Soil Sampling and Analysis}

Soils for the incubation experiment were collected from the copper smelting area in SW Poland $\left(16^{\circ} 01^{\prime} 40^{\prime \prime}\right.$ $\left.\mathrm{N}, 51^{\circ} 45^{\prime} 09^{\prime \prime} \mathrm{E}\right)$, in two open afforested spots $2.45 \mathrm{~km}$ southeast (sampling point 1) and $2.75 \mathrm{~km}$ northeast (sampling point 2) of the smelter. These areas are a former protection zone of the copper smelter established in the early 1990s. Despite the smelter operator reducing heavy metal emissions up to $97 \%$ during the last decades, there are still elevated concentrations of $\mathrm{Cu}, \mathrm{Pb}, \mathrm{Zn}, \mathrm{Cd}, \mathrm{As}$ and $\mathrm{Hg}$ that can be determined in surface soil layers.

Bulk soil samples were collected from $0-20 \mathrm{~cm}$ depth and air dried at room temperature for 14 days. Dry samples were homogenized and sieved $(<2 \mathrm{~mm})$. Basic properties of soils and total contents of $\mathrm{Cu}$, $\mathrm{Zn}, \mathrm{Pb}$ and $\mathrm{Cd}$ are presented in Table 1. Particle size distribution in soil samples was performed using the aerometric method [24]. In soil samples, $\mathrm{pH}$ was measured in distilled water at a ratio of 1:25 (w/v) biochar/water with a Mettler-Toledo SevenMulti dual $\mathrm{pH} /$ conductivity meter. Cation exchange capacity (CEC) and base saturation of tested soil was estimated from equation between $1 \mathrm{M} \mathrm{KCl}$ exchangeable acidity and exchangeable $\mathrm{Ca}^{2+}, \mathrm{Mg}^{2+}, \mathrm{Na}^{+}$, and $\mathrm{K}^{+}$measured at $\mathrm{pH}$ 7 with $1 \mathrm{M}$ ammonium acetate [24] on an MP-AES 4200 microwave plasma atomic emission spectrometer (Agilent Technologies). Organic carbon content was measured on a Shimadzu TOC analyzer. Semi-total contents of elements after microwave digestion with 10 $\mathrm{ml}$ of $\mathrm{HNO}_{3}$ (method EPA 3051A) were measured on an Agilent Technologies MP-AES 4200. To avoid analytical errors, standard solutions (from LGC Standards Ltd.) for MP-AES 4200 were used for calibration, and certified reference materials (ERM-CC1136a and CRM052) were analyzed with every sample set. Each sample analyzed on the MP-AES 4200 was measured as an average from triplicate with the standard deviation, calculated by MP Expert Software Agilent Technologies.

\section{Biochar Production and Analysis}

Wheat-straw-derived biochar (WSBC) was produced at the treatment temperature of $550^{\circ} \mathrm{C}$ using a fast 
pyrolysis method under limited oxygen supply, and remaining time in the reactor of $30 \mathrm{~s}$. For chemical characterization of WSBC (Table 1) the $\mathrm{pH}\left(\mathrm{H}_{2} \mathrm{O}\right)$ was measured. Elemental composition ( $\mathrm{CHN})$ was determined by elemental analyzer (CE Instruments). The ash content was determined by dry combustion in $550^{\circ} \mathrm{C}$ [24]. The specific surface area (SSA) was obtained by $\mathrm{N}_{2}$-BET method using a TrisStar II 3020 surface area analyzer. Oxygen content and atomic ratios $\mathrm{C}: \mathrm{N}, \mathrm{H}: \mathrm{C}$, and $\mathrm{O}: \mathrm{C}$ were calculated to IBI standards in order to estimate aromaticity and polarity of biochar. All analyses were performed in six replicates.

\section{Pot Experiment Set-Up}

Twenty-four pots of $4 \mathrm{~L}$ volume, holding approx. $3 \mathrm{~kg}$ of soil were prepared. Six pots were set as controls without biochar amendment, and six with one dose of BC $(5.0 \% \mathrm{w} / \mathrm{v})$ for both soil types. The dose was chosen based on previous wheat straw biochar experiments as the lowest effective dose. To create the treatments, soil and $\mathrm{BC}$ were mixed and homogenized in pots for $72 \mathrm{~h}$. Soil mixtures were incubated for two years with the humidity of the pots maintained at $60 \%$ of maximum water-holding capacity by weighing the pots weekly and adding water as required. No mineral or organic fertilizer was applied.

\section{Analysis of Speciation of Heavy Metals in Soil}

To investigate the effects of wheat straw biochar on metal speciation and mobility in tested soils the BCR sequential extraction procedure proposed by the European Community Bureau of Reference (BCR) was performed. The BCR method is viewed as one of the most widely applicable extraction procedures for metal speciation in soils, and four sequential extraction steps were performed to obtain four different fractions of metals [25]. The obtained extracts were analyzed for heavy metals by the MP-AES 4200 microwave plasma atomic emission spectrometer (Agilent Technologies).

\section{Statistical Analysis}

A one-way analysis of variance was undertaken for each treatment to determine significant differences among the treatments at $\mathrm{p}<0.05$. Variations in the treatment were determined by calculating the standard deviation (SD). The significant effects for various treatments were detected using t-tests following Fishers Test. The obtained data were compiled using Microsoft Excel 2016 and Statistica Statsoft 13.1. Each value represents the mean from six replicates \pm SD for soil and biochar samples.
Table 1. Properties of soils and wheat straw biochar.

\begin{tabular}{|c|c|c|c|c|}
\hline \multicolumn{2}{|c|}{ Properties } & Sandy & Loamy & Biochar \\
\hline \multirow{4}{*}{$\begin{array}{c}\text { Texture } \\
(\%)\end{array}$} & $2.0-0.05 \mathrm{~mm}$ & 73 & 42 & 77 \\
\hline & $0.05-0.02 \mathrm{~mm}$ & 12 & 34 & 10 \\
\hline & $0.02-0.002 \mathrm{~mm}$ & 14 & 20 & 2 \\
\hline & $<0.002 \mathrm{~mm}$ & 1 & 4 & 1 \\
\hline \multicolumn{2}{|c|}{$\mathrm{pH}\left(\right.$ in $\left.\mathrm{H}_{2} \mathrm{O}\right)$} & 3.9 & 6.4 & 9.86 \\
\hline \multicolumn{2}{|c|}{ TOC (\%) } & 0.98 & 1.12 & 55 \\
\hline \multicolumn{2}{|c|}{$\mathrm{CEC}\left(\mathrm{cmol} \mathrm{kg}^{-1}\right)$} & 5.51 & 58.4 & 63 \\
\hline \multicolumn{2}{|c|}{ Base saturation (\%) } & 64.9 & 71.3 & 100 \\
\hline \multicolumn{2}{|c|}{$\mathrm{Ca}^{2+}\left(\mathrm{cmol} \mathrm{kg}^{-1}\right)$} & 6.5 & 36.4 & 7.4 \\
\hline \multicolumn{2}{|c|}{$\mathrm{Mg}^{2+}\left(\mathrm{cmol} \mathrm{kg}^{-1}\right)$} & 1.8 & 5.1 & 4.5 \\
\hline \multicolumn{2}{|c|}{$\mathrm{K}^{+}\left(\mathrm{cmol} \mathrm{kg}^{-1}\right)$} & 0.8 & 8.5 & 57.0 \\
\hline \multicolumn{2}{|c|}{$\mathrm{Na}^{+}\left(\mathrm{cmol} \mathrm{kg}^{-1}\right)$} & 1.6 & 8.3 & 0.59 \\
\hline \multicolumn{2}{|c|}{$\mathrm{CaCO}_{3}(\%)$} & - & - & 3.36 \\
\hline \multicolumn{2}{|c|}{$\mathrm{N}_{\mathrm{t}}(\%)$} & 0.87 & 0.94 & 0.62 \\
\hline \multicolumn{2}{|c|}{ H (\%) } & - & - & 1.63 \\
\hline \multicolumn{2}{|c|}{$\mathrm{O}(\%)$} & - & - & 10.3 \\
\hline \multicolumn{2}{|c|}{ Ash (\%) } & - & - & 32 \\
\hline \multicolumn{2}{|c|}{$\mathrm{C}: \mathrm{N}$} & 1 & 1.2 & 88 \\
\hline \multicolumn{2}{|r|}{$\mathrm{H}: \mathrm{C}$} & - & - & 0.03 \\
\hline \multicolumn{2}{|r|}{$\mathrm{O}: \mathrm{C}$} & - & - & 0.25 \\
\hline \multicolumn{2}{|c|}{$\operatorname{SSA}\left(\mathrm{m}^{2} \mathrm{~g}^{-1}\right)$} & - & - & 239 \\
\hline \multicolumn{2}{|c|}{$\mathrm{Cu}_{\mathrm{tot}}\left(\mathrm{mg} \mathrm{kg}^{-1}\right)$} & 75 & 210 & 11 \\
\hline \multicolumn{2}{|c|}{$\mathrm{Pb}_{\text {tot }}\left(\mathrm{mg} \mathrm{kg}^{-1}\right)$} & 45 & 65 & 2 \\
\hline \multicolumn{2}{|c|}{$\mathrm{Zn}_{\text {tot }}\left(\mathrm{mg} \mathrm{kg}^{-1}\right)$} & 29 & 31 & 38 \\
\hline \multicolumn{2}{|c|}{$\mathrm{Cd}_{\mathrm{tot}}\left(\mathrm{mg} \mathrm{kg}^{-1}\right)$} & 3.6 & 3.8 & $<0.01$ \\
\hline
\end{tabular}

TOC - total organic carbon, $\mathrm{N}_{\mathrm{t}}$ - total nitrogen content, CEC - cation exchange capacity

SSA - specific surface area, tot - total or semi total content of the element. The values are mean of six analyses $\pm \mathrm{SD}$

\section{Results}

\section{Soil Characterization}

Soil in sampling point 1 had a silt loam texture and was classified as Cutanic Luvisol (FAO-WRB 2014). Soil in sampling point 2 had a loamy sand texture and was classified as Fulvic Brunic Arenosol (FAO-WRB 2014). Luvisols and Arenosols dominate in the areas impacted by smelting and mining objects in SW Poland but also represent a wide range of soil types characteristic of Eastern and Northern Europe. 
In sandy soil (SS), copper exhibited the highest value of $75 \mathrm{mg} \mathrm{kg}$, followed by $45 \mathrm{mg} \mathrm{kg}$, $15 \mathrm{mg} \mathrm{kg}^{-1}$ and $3.6 \mathrm{mg} \mathrm{kg}^{-1}$ of $\mathrm{Pb}, \mathrm{Zn}$ and $\mathrm{Cd}$, respectively. In loamy soil (LS), content of copper was highest and reached $210 \mathrm{mg} \mathrm{kg}^{-1}$, followed by $\mathrm{Pb}-65 \mathrm{mg} \mathrm{kg}^{-1}$. The abundance of $\mathrm{Zn}$ and $\mathrm{Cd}$ was similar to SS, achieving $31 \mathrm{mg} \mathrm{kg}^{-1}$ and $3.8 \mathrm{mg} \mathrm{kg}^{-1}$, respectively. According to Polish law regulation only cadmium content exceeded the soil standards ( $2 \mathrm{mg} \mathrm{kg}^{-1}$ in loamy soils). Contents of all the studied elements were similar to the average (measured in top layers $0-30 \mathrm{~cm}$ ) for Cutanic Luvisols and Arenosols [26, 27] measured in the past in the same locations.

\section{Biochar Characterization}

The properties of biochar depend on the type of feedstock and the pyrolysis conditions. Wheat strawderived biochar (WSBC) used in the experiment had a very fine "powdery" particle structure. Particle size distribution determined by the progressive dry sewing method showed that over $75 \%$ of the material sample had particle diameter $<1 \mathrm{~mm}$. The $\mathrm{pH}$ of biochar produced at $550^{\circ} \mathrm{C}$ was 9.9 as expected and reported in other studies. Material was carbon reach, average $\mathrm{C}_{\text {tot }}$ was $55 \%$. The elemental composition and atomic ratios are given in Table 1. Low $\mathrm{H}: \mathrm{C}$ and $\mathrm{O}: \mathrm{C}$ ratios show high aromaticity and stability of the material [28]. When biochar is applied to soil, the risk of secondary pollution with various elements derived from the material also has to be considered. To verify if the wheat straw biochar is sufficient for soil application, concentrations analyzed in the experiment heavy metals were tested on raw material as well. According to IBI Standards, content of all elements was very low: $\mathrm{Cu}-11 \mathrm{mg} \mathrm{kg}{ }^{-1}, \mathrm{Zn}-38 \mathrm{mg} \mathrm{kg}{ }^{-1}, \mathrm{~Pb}-2 \mathrm{mg} \mathrm{kg}{ }^{-1}$, and $\mathrm{Cd}<0.01 \mathrm{mg} \mathrm{kg}^{-1}$, and contributions of these elements to total contents of $\mathrm{HM}$ in soil were insignificant for $\mathrm{Cu}$, $\mathrm{Pb}$ and $\mathrm{Cd}$ (Table 1).

\section{Effects of Biochar on Soil $\mathrm{pH}$ and Sorption Properties}

Changes in soil $\mathrm{pH}$ and CEC after two-year incubation with wheat straw biochar are presented in Fig. 1. $\mathrm{pH}$ increased significantly $(\mathrm{p}<0.05)$ in acidic sandy soil. Compared to the control, the addition of $5 \%$ WSBC increased soil $\mathrm{pH}$ by 0.85 unit, from $\mathrm{pH} 3.9$ to $\mathrm{pH} 4.75$ in $\mathrm{BC}$ soil. In loamy soil with higher $\mathrm{pH}$ of 6.4 there was no significant increase of $\mathrm{pH}$ after two years of incubation. WSBC application had the opposite effect on CEC values of both tested soils. SS soil saw a significant increase, while in LS a significant decrease of cation exchange was observed after two years from biochar application (Fig. 1). Biochar addition caused a significant $(\mathrm{p}<0.05)$ increase of base cation saturation from $77 \%$ in SS control to $86 \%$ in WSBC SS, and a decrease of soil acidity respectively, from $3.1 \mathrm{cmol} \mathrm{kg}^{-1}$ to $1.8 \mathrm{cmol} \mathrm{kg}^{-1}$. In LS soil no significant changes of base cation saturation and soil acidity was observed. Wheat straw biochar increased exchangeable $\mathrm{K}^{+}, \mathrm{Ca}^{2+}$, $\mathrm{Mg}^{2+}$, and $\mathrm{Na}^{+}$, but the change was only significant for $\mathrm{K}^{+}$for both tested soils.
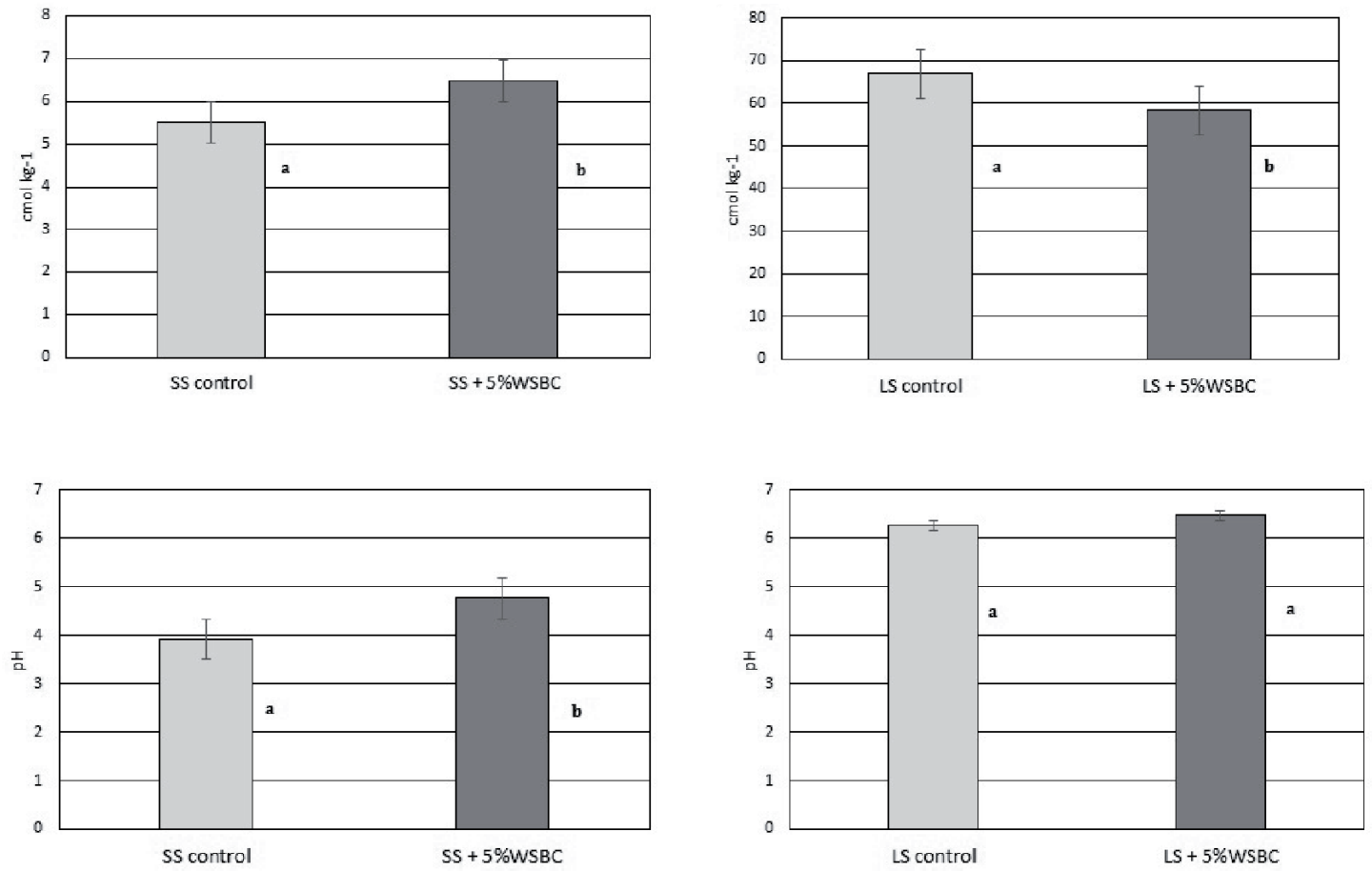

Fig. 1. Effect of wheat straw biochar on soil $\mathrm{pH}$ and CEC in tested soil: $\mathrm{SS}$ - sandy soil and LS - loamy soil; different letters above the graphs indicate significant $(\mathrm{p}<0.05)$ differences between treatments. 


\section{Sequential Extraction of $\mathrm{Cu}, \mathrm{Zn}, \mathrm{Pb}$ and $\mathrm{Cd}$}

In control sandy soil (SS) with low pH value, readily exchangeable/acid soluble $\mathrm{Cu}$ concentrations (fraction F1) were much higher (37\%) compared to loamy soil (LS), with higher $\mathrm{pH}$ value (8\%). In LS most of the copper was already in residual and oxidizable fractions and no effect on $\mathrm{Cu}$ fractionation was observed in biochar treatments after an incubation period (Fig. 2). Significant change after biochar application was observed in SS soil, were reduction of F1 by $30 \%$ was observed and most $\mathrm{Cu}$ was transferred to residual $\mathrm{F} 4$ fraction. Content of $\mathrm{Cu}$ in residual forms increased by $36 \%$ in WSBC sandy soil. There was no significant change in fractions F2 and F3 after the WSBC incorporation and incubation period. Copper in control SS was distributed in the following sequence:
$\mathrm{F} 1>\mathrm{F} 2>\mathrm{F} 3>\mathrm{F} 4$, while in WSBC SS it was $\mathrm{F} 1=\mathrm{F} 4>\mathrm{F} 3>\mathrm{F} 2$ (Fig. 2). Surprisingly, wheat straw biochar had a distinct effect on $\mathrm{Zn}$ immobilization in tested soils. In acidic sandy soil the most extractable $\mathrm{Zn}$ occurred in the soluble/exchangeable fraction (F1). The application of WSBC caused an increase in Zn mobility and the element was transferred from residual fraction (F4) to exchangeable/acid soluble fraction (F1) and reducible fraction (F2). The opposite was seen in loamy soil with higher $\mathrm{pH}$ values as zinc was already in immobile forms, mainly in fraction F2, and biochar application caused $\mathrm{Zn}$ to shift to residual forms (F4). The mobility of $\mathrm{Pb}$ in tested soil was low compared to $\mathrm{Cu}, \mathrm{Zn}$ and $\mathrm{Cd}$ - not exceeding 3\% of total content in sandy soil and $2 \%$ in loamy soil. Lead speciation was highly impacted by WSBC application in SS treatment (Fig. 2). However, no effect was observed on $\mathrm{Pb}$ speciation in LS treatment
$\mathrm{Cu}$

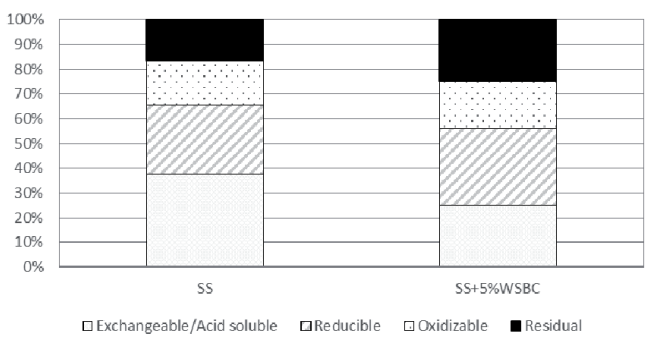

$\mathrm{Zn}$

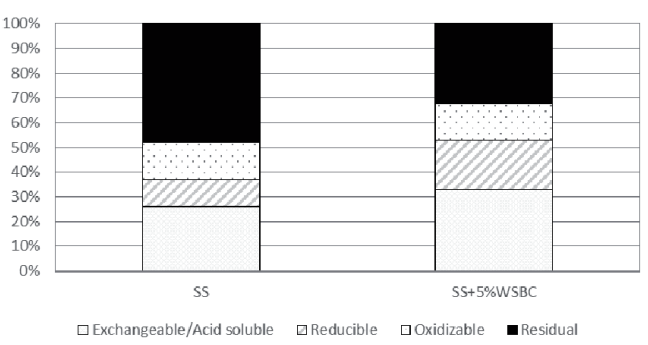

$\mathrm{Pb}$

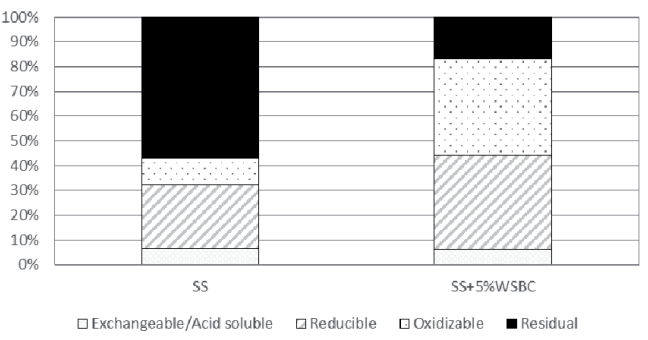

Cd

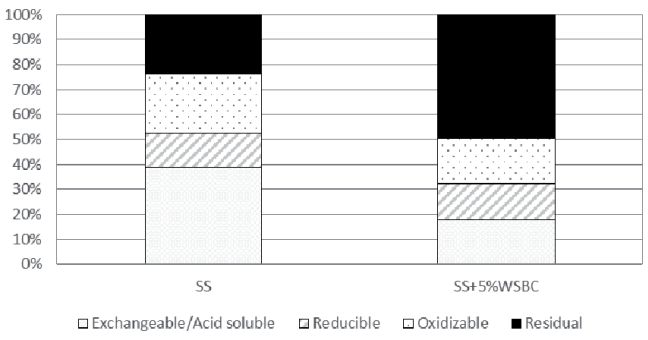

$\mathrm{Cu}$

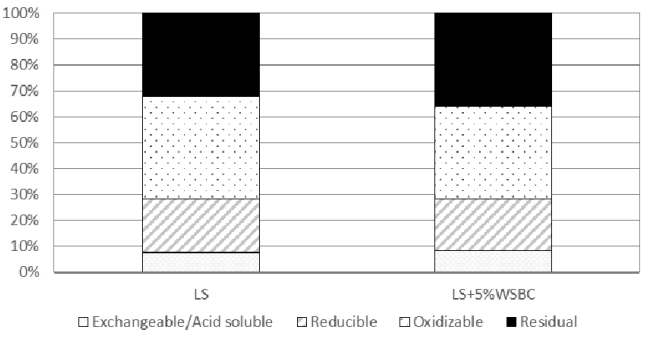

$\mathrm{Zn}$

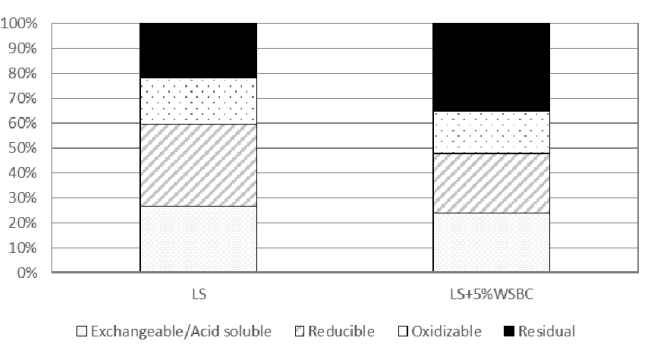

$\mathrm{Pb}$

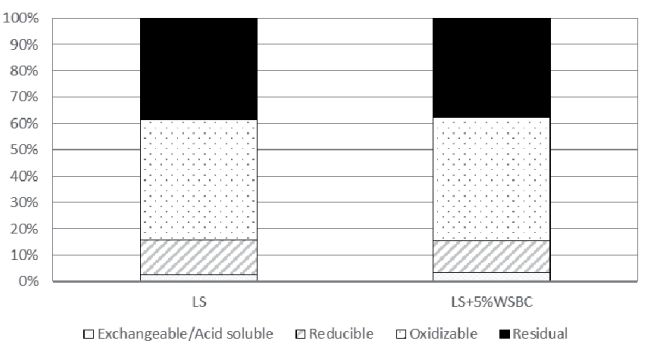

$\mathrm{Cd}$

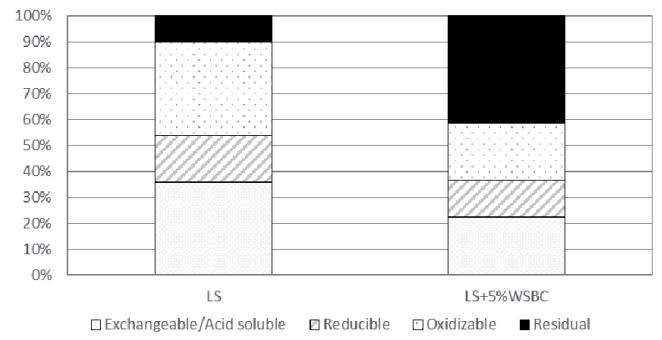

Fig. 2. Variation of $\mathrm{Cu}, \mathrm{Zn}, \mathrm{Pb}$ and $\mathrm{Cd}$ species in soils after wheat straw application: $\mathrm{SS}-$ sandy soil control, $\mathrm{SS}+5 \% \mathrm{WSBC}-\mathrm{sandy}$ soil with 5\% wheat straw biochar, LS- loamy soil control, and LS-5\%WSBC - loamy soil with 5\% wheat straw biochar. 
(Fig. 4). Biochar application in SS caused a shift from residual fraction to oxidizable (bonded with organic matter) F3 and reducible F2 fraction. An increase in F3 was statistically significant in SS $+5 \% \mathrm{WSBC}$ treatment $(\mathrm{p}<0,05)$ compared with control SS, at $39 \%$ and $11 \%$, respectively. The chemical fractionation results of smelter-impacted soils showed that wheat straw biochar application significantly reduced the mobility of $\mathrm{Cd}$ in both tested soils. The greatest change was observed for exchangeable and acid-soluble fractions (F1). The content of $\mathrm{Cd}$ in fraction $\mathrm{F} 1$ decreased from 39\% in control SS to $18 \%$ in $\mathrm{SS}+5 \% \mathrm{WSBC}$ treatment, and from $36 \%$ to $22 \%$ in $\mathrm{LS}+5 \% \mathrm{WSBC}$ treatment. Most of the cadmium forms were shifted to residual fraction $\mathrm{F} 4$, resulting in Cd immobilization, from $23 \%$ to $49 \%$ in $\mathrm{SS}+5 \% \mathrm{WSBC}$ treatment, and from $10 \%$ to $42 \%$ in LS $+5 \%$ WSBC treatment.

\section{Discussion}

Wheat straw biochar used in the experiment had high ash content and high specific sorption, which can be attributed to feedstock type and high pyrolysis temperature $\left(550^{\circ} \mathrm{C}\right)$. With increasing temperature of the process also surface area and charge density on the $\mathrm{BC}$ surface increase, which makes high temperature biochars more sufficient as sorbents. Compared to other biochars made from different feedstock types like rice straw $\left(45 \mathrm{cmol} \mathrm{kg}^{-1}\right)$ or bamboo (15 cmol $\left.\mathrm{kg}^{-1}\right)$ [22], CEC of wheat straw biochar was higher (Table 1). Another important property of material affecting sorption behavior and the potential for soil alkalization is ash content. Wheat straw biochar had high ash content (Table 1) and as a result, more effective precipitation and immobilization of metals can be expected. Alkaline $\mathrm{pH}$ of biochar and high CEC affected basic soil properties significantly in cases of sandy soil, while in loamy soil with higher $\mathrm{pH}$ and better sorption properties the effect was less significant. Observed increases of soil $\mathrm{pH}$ after biochar application to sandy soil is in agreement with Bian et al. [29] or Yang et al. [30]. Similar results for BC amendment soil were described by Masud et al. [31]. The potential of $\mathrm{H}^{+}$dissociation [5] in alkaline $\mathrm{pH}$ that can occur in biochar-amended soils can be important information for predicting biochar ability for heavy metal sorption, which is due to the process of $\mathrm{H}^{+}$exchange for metal cations and the increase of negative load of BC. The decrease in soil acidity induced by the biochar amendment responds with the increase of $\mathrm{BC}$ soil $\mathrm{pH}$ mentioned above. Biochars can also comprise ample oxygen-containing functional groups that can form surface complexes with $\mathrm{Al}^{3+}$ [32]. This process also contributes to the decrease of soil acidity and is similar to the one that occurs when organic matter is applied to the acidic soil [33].

Different mechanisms of heavy metal immobilization can be observed after biochar application. First, biochar can influence soil properties determining element mobility like $\mathrm{pH}$ or cation exchange capacity. Secondly, biochar can support soil sorption complexes and accomplish trace element immobilization by several mechanisms, including metal exchange, complexation with different functional groups on biochar [12], and specific and nonspecific adsorption [28], which can be partly determined during sequential extraction procedure. Depending on initial $\mathrm{pH}$ values of soil, element mobility and biochar properties (ash content, specific sorption area, functional groups, etc.) the effect of biochar application may vary between soil types. Arenosols and Luvisols represent soils with very distinct properties and different effects on heavy metal immobilization/mobilization was observed after biochar application. In general, in acidic sandy soil low $\mathrm{pH}$ values determined higher initial mobility of tested trace elements, and $\mathrm{pH}$ increase was the dominant mechanism of their immobilization after WSBC application. In loamy soil with $\mathrm{pH}$ above 6.0 , the increase of $\mathrm{pH}$ after biochar application was insignificant and precipitation and surface complexation reactions dominate biochar's remediation capacity [19], causing a shift of metals between fractions, but not resulting in significant changes in their mobility. It is also likely that increases of soil $\mathrm{pH}$ after biochar application to tested sandy soil promoted heavy metal adsorption and precipitation processes $[29,34,35]$. Wheat straw biochar had high ash content and most of the mineral elements were in the forms of carbonates and bicarbonates (Table 1) or oxides and orthophosphates [23]. These compounds are alkaline after dissolving in water and contribute to short-term amelioration $[10,36]$, as well as promote the formation of hydroxide complexes, phosphates or carbonates [6], $\mathrm{Cd}$ as $\mathrm{CdCO}_{3} \mathrm{Cu}$ as $\mathrm{Cu}(\mathrm{OH})_{2}$ and $\mathrm{Pb}$ as $\mathrm{Pb}_{5}\left(\mathrm{PO}_{4}\right)_{3} \mathrm{OH}[12,22]$, which was observed after sequential extraction of heavy metals from tested soils. The immobilization effect varied between elements, showing different sensitivities to $\mathrm{pH}$ change or different affinity to biochar. Copper was sensitive to $\mathrm{pH}$ change and the effect of immobilization was only observed in SS treatment. Similar findings were observed by Moore et al. [37], where biochar application to $\mathrm{Cu}$-contaminated soil in the vicinity of the Vantanas $\mathrm{Cu}$ smelter in Chile increased soil $\mathrm{pH}$ and decreased the $\mathrm{Cu}$ exchangeable fraction by 5 and 10 times by increasing the $\mathrm{Cu}$ bound in organic matter and residual fractions. Concurrently, an increase of CEC in sandy soil suggests that biochar can support sorption capacity for cations like $\mathrm{Cu}^{2+}$. Tong et al. [38] determined that $\mathrm{Cu}$ (II) can be adsorbed specifically through the formation of surface complexes with $-\mathrm{COOH}$ and phenolic hydroxyl groups on biochar surfaces. Zinc in alkaline soils is immobile, which can explain the shift to residual forms in LS+ $5 \% \mathrm{WSBC}$ treatment, were $\mathrm{pH}$ increased from slightly acidic to alkaline. In sandy acidic soil, increases of exchangeable/ soluble faction F1 were observed. Ippolito et al. [39] showed that with increasing application rates of biochar, zinc tended to decrease in the residual fraction and increase in the soluble/exchangeable/carbonate fraction. 
Wheat straw biochar could be a donor of easily soluble forms of $\mathrm{Zn}$ and caused enrichment of this element in tested soil (Table 1). To verify this thesis, soluble forms of $\mathrm{Zn}$ were determined in biochar after extraction with $0.11 \mathrm{M}$ acetic acid as per BCR protocol. Compared with amounts of $\mathrm{Zn}$ determined as a soluble fraction (F1) in control soil and BC soil (3.6 $\mathrm{mg} \mathrm{kg}^{-1}$ and $5.9 \mathrm{mg} \mathrm{kg}^{-1}$, respectively) the content of $0.11 \mathrm{M}$ HOAc-extractable $\mathrm{Zn}$ in biochar was high (3.0 mg kg-1) and might contribute to the content of exchangeable/acid soluble fraction extracted from soil $+\mathrm{BC}$ mix during $\mathrm{BCR}$ sequential extraction, giving a false result of element shift. The increase of F1 fraction could also be explained by $\mathrm{Zn}$ complexation by acetate [40]. The application of biochar increased soil alkalinity, which can cause $\mathrm{Zn}^{2+}$ hydrolysis and promote the formation of easily soluble salts like $\mathrm{Zn}(\mathrm{OAc})_{2}$, which can explain the changes in $\mathrm{Zn}$ mobility in tested sandy soil. $\mathrm{Xu}$ et al. [41] suggested that the probable mechanism of $\mathrm{Zn}$ immobilization behavior depends on the ash content in biochar and the occurrence of easily soluble minerals like $\mathrm{PO}_{4}{ }^{3-}$ and $\mathrm{CO}_{3}{ }^{2-}$. They were probably released from biochar and could react with $\mathrm{Zn}^{2+}$ to form easily soluble $\mathrm{Zn}$ phosphates and $\mathrm{Zn}$ carbonates, increasing amounts of fraction F1 during the first step of BCR extraction. Also, increases in F2 fraction in SS were observed after biochar application, which can be explained by chemical precipitation processes occurring on wheat straw biochar surface upon the formation of oxides. Qian et al. [42] suggested that high-temperature biochars contain higher amounts of $\mathrm{OH}^{-}, \mathrm{CO}_{3}{ }^{2-}$ and $\mathrm{Si}$ species or other sorption sites like oxygen-containing functional groups. We suggest that the formation of oxide $\mathrm{Zn}$ species on high temperature wheat straw biochar surface caused an increase of reduced $\mathrm{Zn}$ forms in fraction F2 during the BCR sequential extraction procedure. Some $\mathrm{Zn}^{2+}$ could also be occluded on $\mathrm{Mn}, \mathrm{Al}$, and $\mathrm{Fe}$ oxides formed on biochar and soil constituent surfaces. As Zn has a lower affinity to be complexed with $\mathrm{Mn}$ and $\mathrm{Fe}$ oxides compared to the other metals like $\mathrm{Pb}$ or $\mathrm{Cd}$, it is probable that it can be a secondary mechanism of $\mathrm{Zn}$ immobilization in tested soils. We postulate that LS alkaline conditions after WSBC treatment could promote the formation of $\mathrm{Zn}(\mathrm{OH})_{2}$, and amorphous hemimorphite could occur. This can explain the increase of $\mathrm{Zn}$ residual fraction, which was also found by Qian et al. [42] for wheat straw biochar produced at $550^{\circ} \mathrm{C}$.

Lead sorption on biochars is controlled by multiple sorption mechanisms: organic functional groups (e.g., $\mathrm{C}-\mathrm{H},-\mathrm{COOH},-\mathrm{OH}, \mathrm{C}=\mathrm{O}$ and $\mathrm{C}-\mathrm{X}$ ), mineral content, ionic content and $\pi$-electrons [43] - all of which should be considered in the case of tested soils. A study in single-contaminant systems demonstrated that four different types of biochar (bamboo-, sugarcane bagasse-, hickory wood- and peanut hull-derived) removed $\mathrm{Pb}^{2+}$ at $18-35 \%$ efficiency. The authors suggested that the adsorption of $\mathrm{Pb}$ may be affected by the pore structure $[36,44]$ directly correlated with the amount of oxygen functional groups on biochars and increase of CEC, which promotes more negative charge and adsorption affinity of soils for $\mathrm{Pb}^{2+}$ [33]. We suggest that biochar renewed stock of organic matter played the most important role in cation exchange and sorption/ desorption processes. Under acidic conditions biochar released $\mathrm{Ca}^{2+}, \mathrm{Mg}^{2+}$ and $\mathrm{K}^{+}$, which was replaced by $\mathrm{Pb}^{2+}$ and which can be confirmed by changes in base cation contribution in the sorption complex described above. The transformation of $\mathrm{Pb}$ from residual (extractable) to non-residual form after biochar addition, might occur concurrently with the formation of lead phosphate and lead hydroxyapatite-like minerals $[45,46]$. This suggests that tested phosphorus reach wheat straw biochar could influence $\mathrm{Pb}$ retention by phosphate formation in $\mathrm{LS}+$ 5\%WSBC treatment.

Fraction F1 from BCR extraction is considered a bioavailable fraction, which is very prone to leaching [47] and wheat straw biochar application reduced significantly the risk of cadmium leaching from copper smelter-impacted soils. In the tested soils changes in oxidizable and bounded with organic (F3) fraction also were observed, with some cadmium forms shifting from fraction F1 to F3. This is possibly due to the precipitation processes on biochar and the formation of insoluble cadmium carbonate hydroxides and organic complexes [19]. The most probable mechanism of cadmium immobilization in tested soils was the increase of soil $\mathrm{pH}$ after biochar application. Soil $\mathrm{pH}$ is a key factor governing $\mathrm{Cd}$ solubility and, therefore, bioavailability. Higher $\mathrm{pH}$ affords more negative surface charge, higher density of $\mathrm{pH}$-dependent exchange sites and increased hydrolysis of Cd [48]. Beesley and Marmiroli [33] found that biochar significantly reduced leachate concentrations of $\mathrm{Cd}$, with evidence of surface sorption to biochar [19]. Cadmium sorption mechanism was also suggested by Fellet et al. [49]. Cui et al. [50], Bian et al. [29] and Puga et al. [16], indicating that biochar can be effective in $\mathrm{Cd}$ immobilization in the contaminated paddy soil. However, this effect in the presented study case was not well reported.

\section{Conclusions}

The effect of biochar application on $\mathrm{Cu}, \mathrm{Zn}, \mathrm{Pb}$ and $\mathrm{Cd}$ immobilization depended strongly on initial soil $\mathrm{pH}$ and varied between soil types. In acidic soils $\mathrm{pH}$ increase after biochar application should be considered as the major factor influencing heavy metal immobilization. On the other hand, in alkaline soil, biochar had no significant effect on $\mathrm{pH}$ increase, although the shifts between metal fraction occurred, suggesting that above $\mathrm{pH} 6.0$ adsorption and precipitation processes on biochar surface dominate in trace element immobilization processes. The application of wheat straw biochar was more successful in sandy acidic soil, causing significant reduction of risk related to heavy metal presence in soil impacted by copper smelting and mining processes. Biochar application significantly reduced Cd mobility 
in both tested soils, suggesting that the addition of this material can be considered as good management practice in soils contaminated with cadmium. Presented results show that the effect of wheat straw biochar on heavy metal immobilization in multi-contaminated soils is more complex and cannot be defined as all-purpose material in remediation procedures.

\section{Conflict of Interest}

The authors declare no conflicts of interest.

\section{References}

1. HAMMOND J., SHACKLEY S., SOHI S., BROWNSORT P. Prospective life cycle carbon abatement for pyrolysis biochar systems in the UK. Energy Policy 39, 2646, 2011.

2. NOVAK J., LIMA I., GASKIN J., STEINER C., DAS K., AHMEDNA M., WATTS D.W., WARREN J., SCHOMBERG H. Characterization of designer biochar produced at different temperatures and their effects on a loamy sand. Annals of Environmental Sciences 3, 195, 2009.

3. SPOKAS K., NOVAK J., VENTEREA R. Biochar's role as an alternative $\mathrm{N}$-fertilizer: Ammonia capture. Plant and Soil 350, 35, 2012

4. BEESLEY L., MARMIROLI M. The immobilisation and retention of soluble arsenic, cadmium and zinc by biochar. Environmental Pollution 159, 474, 2011.

5. PARK J.H., LAMB D., PANEERSELVAM P., CHOPPALA G., BOLAN N., CHUNG J. Role of organic amendments on enhanced bioremediation of heavy metal(loid) contaminated soils. Journal of Hazardous Materials 185, 549, 2011.

6. KOŁODYŃSKA D., WNETRZAK R., LEAHY J., HAYES M., KWAPIŃSKI W., HUBICKI Z. Kinetic and adsorptive characterization of biochar in metal ions removal. Chemical Engineering Journal 197, 295, 2012.

7. HOUBEN D., EVRARD L., SONNET P. Beneficial effects of biochar application to contaminated soils on the bioavailability of $\mathrm{Cd}, \mathrm{Pb}$ and $\mathrm{Zn}$ and the biomass production of rapeseed (Brassica napus L.). Biomass and Bioenergy, 57, 196, 2013.

8. ZHENG H., WANG Z., DENG X., ZHAO J., LUO Y., NOVAK J., HERBERT S., XING B. Characteristics and nutrient values of biochars produced from giant reed at different temperatures. Bioresource Technology 130, 463, 2013.

9. LIU C., CHU W., LI H.,BOYD S.,TEPPEN B.,MAO J. Quantification and characterization of dissolved organic carbon from biochars. Geoderma 335, 161, 2019.

10. FIDEL R., LAIRD D.,THOMPSON M., LAWRINENKO M. Characterization and quantification of biochar alkalinity. Chemosphere 167, 367, 2017.

11. UCHIMIYA I., LIMA K., KLASSON L., WARTELLE L. Contaminant immobilization and nutrient release by biochar soil amendment: roles of natural organic matter. Chemosphere 80, 935, 2010.

12. CAO X., MA L., LIANG Y., GAO B., HARRIS W. Simultaneous immobilization of lead and atrazine in contaminated soils using dairy-manure biochar. Environmental Science \& Technology 45, 4884, 2011.
13. PARK J., CHOPPALA G., BOLAN N., CHUNG J., CHUASAVATHI T. Biochar reduces the bioavailability and phytotoxicity of heavy metals. Plant and Soil, 348, 439, 2011

14. AHMAD M., SOO S., DOU X., MOHAN D., SUNG J., YANG J., SIK Y. Effects of pyrolysis temperature on soybean stover- and peanut shell-derived biochar properties and TCE adsorption in water. Bioresource technology, 118, 536,2012

15. VON GUNTEN K.,ALAM M.,HUBMANN M.,OK Y., KONHAUSER K.,ALESSI D. Modified sequential extraction for biochar and petroleum coke: Metal release potential and its environmental implications. Bioresource Technology 236, 106, 2017.

16. PUGA A., MELO L., DE ABREU C., COSCIONE A., PAZ-FERREIRO J. Leaching and fractionation of heavy metals in mining soils amended with biochar. Soil and Tillage Research, 164, 25, 2016.

17. WANG F., SUN H., REN X., LIU Y., ZHU H., ZHANG P., REN C. Effects of humic acid and heavy metals on the sorption of polar and apolar organic pollutants onto biochars. Environmental Pollution 231, 229, 2017.

18. CAO X., HARRIS W. Properties of dairy-manure-derived biochar pertinent to its potential use in remediation. Bioresource Technology, 101, 5222, 2011.

19. VAN POUCKE R., AINSWORTH J., MAESEELE M., OK Y., MEERS E., TACK F. Chemical stabilization of Cdcontaminated soil using biochar. Applied Geochemistry, 88, $122,2018$.

20. BEESLEY M., MORENO-JIMÉNEZ E., GOMEZ-EYLES J. Effects of biochar and greenwaste compost amendments on mobility, bioavailability and toxicity of inorganic and organic contaminants in a multi-element polluted soil. Environmental Pollution, 158, 2282, 2010.

21. JIANG T., JIANG J., XU R., LI Z. Adsorption of Pb(II) on variable charge soils amended with rice-straw derived biochar. Chemosphere, 89, 249, 2012.

22. LU K., YANG X., SHEN J., ROBINSON B., HUANG H., LIU D., BOLAN N., PEI J., WANG H. Effect of bamboo and rice straw biochars on the bioavailability of $\mathrm{Cd}$, $\mathrm{Cu}, \mathrm{Pb}$ and $\mathrm{Zn}$ to Sedum plumbizincicola. Agriculture, Ecosystems and Environment, 191, 124, 2014.

23. DAI S., LI H., YANG Z., DAI M., DONG X., GE X., SUN M., SHI L. Effects of biochar amendments on speciation and bioavailability of heavy metals in coalmine-contaminated soil. Human and Ecological Risk Assessment. 24, 1, 2018.

24. CARTER M., GREGORICH E. Soil Sampling and Methods of Analysis, CRC Press, 2006.

25. ŽEMBERYOVÁ M., BARTEKOVÁ J., HAGAROVÁ I. The utilization of modified BCR three-step sequential extraction procedure for the fractionation of $\mathrm{Cd}, \mathrm{Cr}, \mathrm{Cu}$, $\mathrm{Ni}, \mathrm{Pb}$ and $\mathrm{Zn}$ in soil reference materials of different origins. Talanta, 70, 973, 2006.

26. KARCZEWSKA A., CHODAK T., KASZUBKIEWICZ J. The suitability of brown coal as a sorbent for heavy metals in polluted soils. Applied Geochemistry, 11, 343-346, 1996.

27. MEDYŃSKA-JURASZEK A., KABAŁA C. Heavy metal pollution of forest soils impacted by copper industry. Journal of Elementology, 17, 441, 2012.

28. ĆWIELĄG-PIASECKA I., MEDYŃSKA-JURASZEK A., JERZYKIEWICZ M., DĘBICKA M., BEKIER J., JAMROZ E.,KAWAŁKO D. Humic acid and biochar as specific sorbents of pesticides. Journal of Soils and Sediments, 18, 2692, 2018. 
29. BIAN R., JOSEPH S., CUI L., PAN G., LI L., LIU X., ZHANG A., RUTLIDGE H., WONG S., CHIA C., MARJO C., GONG B., MUNROE P., DONNE S. A threeyear experiment confirms continuous immobilization of cadmium and lead in contaminated paddy field with biochar amendment. Journal of Hazardous Materials, 272, 121, 2014.

30. YANG X., LIU J., MCGROUTHER K., HUANG H., LU K., GUO X., HE L., LIN X., CHE L., YE Z., WANG Z. Effect of biochar on the extractability of heavy metals $(\mathrm{Cd}$, $\mathrm{Cu}, \mathrm{Pb}$, and $\mathrm{Zn}$ ) and enzyme activity in soil. Environmental Science and Pollution Research, 23, 974, 2016.

31. MASUD M., JIU-YU L., REN-KOU X. Use of alkaline slag and crop residue biochars to promote base saturation and reduce acidity of an acidic Ultisol. Pedosphere 24, 791, 2014.

32. JIANG J., KOU XU R., YU JIANG Z., LI Z. Immobilization of $\mathrm{Cu}(\mathrm{II}), \mathrm{Pb}(\mathrm{II})$ and $\mathrm{Cd}(\mathrm{II})$ by the addition of rice straw derived biochar to a simulated polluted Ultisol. Journal of Hazardous Materials, 229-230, 145, 2012.

33. BEESLEY L., MARMIROLI M. The immobilisation and retention of soluble arsenic, cadmium and zinc by biochar. Environmental Pollution, 159, 474, 2010.

34. ZHANG L., YANG SUN X., TIAN Y., QIANG GONG Y. Biochar and humic acid amendments improve the quality of composted green waste as a growth medium for the ornamental plant Calathea insignis. Scientia Horticulturae, 176, 70, 2014.

35. WANG M., ZHU Y., CHENG L., ANDSERSON B., ZHAO X., WANG D., DING A. Review on utilization of biochar for metal-contaminated soil and sediment remediation. Journal of Environmental Sciences, 63, 156, 2017.

36. WANG H., YANG X., HE L., LU K., MÜLLER K., MCGROUTHER K., XU S., ZHANG X., LI J., HUANG H., YUAN G., HU G., LIU X. Using biochar for remediation of contaminated soils. Twenty Years of Research and Development on Soil Pollution and Remediation in China, 763, 2018.

37. MOORE F., GONZÁLEZ M.,KHAN N., CURAQUEO G., SANCHEZ-MONEDERO M., RILLING J., MORALES E., PANICHINI M., MUTIS A., JORQUERA M., MEJIAS J., HIRZEL J., MEIER S. Copper immobilization by biochar and microbial community abundance in metalcontaminated soils. Science of the Total Environment, 616-617, 960, 2018.

38. TONG X., LI J., YUAN J., XU R. Adsorption of $\mathrm{Cu}(\mathrm{II})$ by biochars generated from three crop straws. Chemical Engineering Journal, 172, 828, 2011.
39. IPPOLITO J., BERRY C., STRAWN D., NOVAK J., LEVINE J., HARLEY A. Biochars reduce mine land soil bioavailable metals. Journal of Environment Quality. 46, 411, 2017

40. UCHIMIYA M., KLASSON K., WARTELLE L., LIMA I. Influence of soil properties on heavy metal sequestration by biochar amendment: 1 . Copper sorption isotherms and the release of cations. Chemosphere, 82, 1431, 2011.

41. XU X., CAO X., ZHAO L., WANG H. Removal of $\mathrm{Cu}$, $\mathrm{Zn}$, and $\mathrm{Cd}$ from aqueous solutions by the dairy manurederived biochar. Environ Sci Pollut Res Int. 20/1, 358, 2013.

42. QIAN T., WANG Y., FAN T., FANG G., ZHOU D. A new insight into the immobilization mechanism of $\mathrm{Zn}$ on biochar: the role of anions dissolved from ash. Nature Publishing Group, 1, 2016.

43. ZAMA E., ZHU Y., REID B., SUN G. The role of biochar properties in influencing the sorption and desorption of $\mathrm{Pb}(\mathrm{II}), \mathrm{Cd}(\mathrm{II})$ and $\mathrm{As}(\mathrm{III})$ in aqueous solution. Journal of Cleaner Production, 148, 127, 2017.

44. ZHOU H., MENG H., ZHAO L., SHEN Y., HOU Y., CHENG H., SONG L. Effect of biochar and humic acid on the copper, lead, and cadmium passivation during composting. Bioresource Technology, 258, 279, 2018.

45. CHEN S., ZHU Y., MA Y., McKAY G. Effect of bone char application on $\mathrm{Pb}$ bioavailability in a $\mathrm{Pb}$-contaminated soil. Environmental Pollution, 139, 433, 2005.

46. KARAMI N., CLEMENTE R., MORENO-JIMÉNEZ E., LEPP N., BEESLEY L. Efficiency of green waste compost and biochar soil amendments for reducing lead and copper mobility and uptake to ryegrass. Journal of Hazardous Materials, 191, 41, 2011.

47. BOGUSZ A., OLESZCZUK P. Sequential extraction of nickel and zinc in sewage sludge- or biochar/sewage sludge-amended soil. Science of the Total Environment, 636, 927, 2018.

48. QI F., DONG Z., LAMB D., NAIDU R., BOLAN N., OK Y., LIU C., KHAN N., JOHIR M., SEMPLE K. Effects of acidic and neutral biochars on properties and cadmium retention of soils. Chemosphere, 180, 564, 2017.

49. FELLET G., MARCHIOL L., DELLE VEDOVE G., PERESSOTTI A. Application of biochar on mine tailings: Effects and perspectives for land reclamation. Chemosphere, 83, 1262, 2011.

50. CUI L., LI L., ZHANG A., PAN G., BAO D., CHANG A. Biochar amendment greatly reduces rice $\mathrm{CD}$ uptake in a contaminated paddy soil: A two-year field experiment. BioResources, 6, 2605, 2011. 
